\title{
Insights into the ecotoxicological perturbations induced by the biocide abamectin in the white snail, Theba pisana
}

Mohamed Radwan ( $\square$ mohamedalymahmoud2020@gmail.com )

Alexandria University Faculty of Agriculture El-Shatby

\section{Amira Gad}

ARC Plant Protection Research Institute

\section{Research Article}

Keywords: Abamectin, endpoints, Theba pisana, Enzymes, Energy reserves

Posted Date: October 22nd, 2021

DOI: https://doi.org/10.21203/rs.3.rs-995720/v1

License: (c) (i) This work is licensed under a Creative Commons Attribution 4.0 International License. Read Full License

Version of Record: A version of this preprint was published at Journal of Environmental Science and Health, Part B on February 22nd, 2022. See the published version at https://doi.org/10.1080/03601234.2022.2044708. 


\section{Abstract}

Abamectin (avermectin B1, ABM) has been widely used as a biocide in agriculture, veterinary and medicine worldwide. In the current study, we aimed to evaluate the acute toxicity and sub-lethal biochemical responses of ABM on the non-target land snail, Theba pisana. Mortality of snails increased with the dose increase, resulting $48 \mathrm{~h}-\mathrm{LD}_{50}$ value of $1.048 \mu \mathrm{g} / \mathrm{snail}$. Sub-lethal effects were studied on the survivors of $20 \%$ and $60 \% \mathrm{LD}_{50} \mathrm{ABM}$ doses and the biochemical parameters were assessed for up to 7 days of exposure. The results showed a decrease in glycogen content and lipids for two sub-lethal doses after all time intervals, whereas increased the level of total proteins after exposure to $60 \% L_{50} A B M$. Overall, the tested sub-lethal doses significantly decreased the total energy reserves. ABM-exposure to snails elevated $\mathrm{\gamma}$-Glutamyl transferase $(\mathrm{\gamma}-\mathrm{GT})$ and Lactate dehydrogenase (LDH) activities at all-time intervals. A significant increase of Glutathione-S-transferase (GST) activity was also recorded in snails exposed to $20 \%$ and $60 \% L_{50}$ after 7 days and all time intervals, respectively. However, $A B M$ inhibited the activity of Aspartate aminotransferase (AST) and Alanine aminotransferase (ALT) after 7 days of exposure. Our investigation provides new insights into the disturbances of energy reserves and enzyme activities in T. pisana snails that can be used as useful sentinel organism. Indeed, these tested biochemical parameters of the snails are sensitive and may be used as biomarkers for assessing ABM toxicity.

\section{Introduction}

Growing anthropogenic activities all over the world have resulted in the subsequent contamination of the environment because of continuously loaded by different types of toxic pollutants including pesticides (Özkara et al. 2016). Consequently, pesticide pollutants have become of great concern due to the adverse effects on human health and non-target organisms (Sharma et al. 2019). Once applied to the target pests, pesticides can reach the terrestrial ecosystem and become bioavailable for assimilation by soil organisms (Sánchez-Bayo 2011). Accordingly, we need to make every effort to assess their ecotoxicological effect as a tool for the risk assessment of contaminated soils.

Abamectin (ABM) is the main avermectin group, which belongs to a 16-membered macrocyclic lactones metabolites produced by a natural fermentation of the bacterium Streptomyces avermitilis (Pitterna et al. 2009). ABM mixture contains more than $80 \%$ avermectin $B 1 a$ and less than $20 \%$ avermectin $B 1 b$ (Fisher and Mrozik 1989). ABM works as a chloride channel activator by binding $\delta$-aminobutyric acid (GABA) receptor and glutamate-gated chloride channels disrupting nerve signals within animals (Jansson and Dybas 1998; Bloomquist 2003). Its novel mode of action, high potency and specific physico-chemical properties make this compound excellent candidate for further insecticidal, acaricidal, and molluscicidal studies (Horowitz and Ishaaya 2004; Radwan 2016).

With regard to the environmental aspects, Lumaret et al. (2012) reviewed the widespread use of ABM has led to environmental consequences for aquatic and terrestrial non-target organisms. In terrestrial ecosystems, the entry of ABM into the environment is through enriching agricultural soil with treated 
animals manure or via livestock excretion on pasture soils. Its physical/chemical properties includes low water solubility, non-volatile and high affinity for lipids and for binding to organic matter in combination with a high rate of excretion of the parent compound from treated animals (Halley et al. 1989), raising concerns among many scientists that found it slowly disappears from the soil with a half-life of 2-8 weeks (Halley et al. 1989; Erzen et al. 2005).

Snails belong to the molluscan class Gastropoda, which inhabit land, freshwater and marine environments. Several herbivorous land snail species including the helicid white garden snail, Theba pisana is utilized as a sensitive indicator for the diagnosis of chemical pollution and climatic changes (de Vaufleury et al. 2006; Regoli et al. 2006; Radwan et al. 2010; Madejón et al. 2013; Nicolai and Ansart 2017). The potential for use of T. pisana as a model organism both in laboratory toxicity tests and in biomonitoring studies as bioindicator of metals and organic soil contamination is well-documented (Radwan et al. 2010; Madejón et al. 2013; El-Gendy et al. 2019).

Biomarkers are early warning tools measured in biological indicator species in response to environmental stressors in a well-known manner, and therefore can be used to assess the threat to an ecosystem in a polluted area (Hamza-Chaffai 2014). Exposure to xenbiotics can induce changes in an organism at the molecular level. Molecular biomarkers are measurable biochemical indicators of cellular effects of toxicity that can supplement the interpretation of observed organismal and population level effects (van der Oost et al. 2003). The usage of cellular and biochemical changes in the hepatopancreas and/or hemolymph of land gastropods as biomarkers of pollutant exposure and effects have been documented (Radwan et al. 2020).

The present study is a series of experiments in our laboratory to use several endpoints for investigating the ecotoxicological impacts of pesticides on the snail, T. pisana as a model organism (Radwan et al. 1992; El-Gendy et al. 2019). Based on the website information of the Agricultural Pesticides Committee (APC) of the Egyptian Ministry of Agriculture and Land Reclamation, the active ingredient of ABM is currently approved for use in 87 different formulated products against 8 different pests on 12 crops (APC, 2021). Despite its extensive use in Egypt, little research had been conducted into the potential adverse effects of $A B M$. To address the gap in data on the potential impacts of $A B M$ on non-target terrestrial snails, our aim of the present study was to evaluate the lethal and sub-lethal toxicity of ABM on the land snail, T. pisana. After 1, 3 and 7 days of exposure, we analyzed the alterations of five enzyme activities; GST, Y-GT, AST, ALT and LDH along with the levels of energy reserve (lipids, glycogen and proteins) in the digestive glands of the animal to examine their utility as popular stress endpoints of pesticides.

\section{Materials And Methods}

\section{Chemicals used}

Commercial formulation of $A B M\left(\right.$ Vertimec ${ }^{\circledR} 18 \mathrm{EC}$ ) with chemical formula: $\mathrm{C}_{48} \mathrm{H}_{72} \mathrm{O}_{14}$ (B1a); $\mathrm{C}_{47} \mathrm{H}_{70} \mathrm{O}_{14}$ (B1b), was used in the present study and supplied by Syngenta Agro Services AG, Egypt. Other reagents 
and chemicals used in the present work were provided by Sigma-Aldrich Company.

\section{Animals tested}

Samples of the land snail, Theba pisana were taken from a non-contaminated Botanic garden (Antoniades) in Alexandria Governorate, Egypt ( $31^{\circ} 12^{\prime} 08^{\prime \prime} N ; 2^{\circ} 57^{\prime} 03^{\prime \prime} E$ ). Before the experiments, they were caged in aerated wood boxes ( $30 \times 25 \times 25 \mathrm{~cm}$, with 100 snails per box) for one month at $25-28^{\circ} \mathrm{C}$, 62-65 RH and LD 12/12 h cycle. The animals were fed ad libitum with fresh Lettuce sativa leaves. Only healthy adult snail with a weight of $0.95 \pm 0.01 \mathrm{~g}$ and a shell diameter of $14.9 \pm 0.082 \mathrm{~mm}$ was used. The experiments were carried out according to the guidelines for animal care and handling, with the approval of the Animal Ethics Committee of Alexandria University.

\section{Lethal toxicity experiment}

To determine the contact median lethal toxicity and the sub-lethal toxicity of ABM on T. pisana snails, topical application method was adopted (Radwan and Mohamed 2013). Stock solution of ABM was prepared by dissolving $0.5 \mathrm{~g}$ of the pesticide in $500 \mathrm{ml}$ of distilled water $(1000 \mu \mathrm{g} / \mathrm{ml})$. ABM was used at various concentrations ranging from 25 to $1000 \mu \mathrm{g} / \mathrm{ml}$, after pilot experiments conducted with $A B M$ at concentrations of 10,100 and $1000 \mu \mathrm{g} / \mathrm{ml}$. Dosage range corresponding to the concentrations described above varying between 0.25 and $10 \mu \mathrm{g} \mathrm{ABM}$ /snail. Three plastic boxes (each box contains ten animals) were utilized for each treatment. Each box was capped with a cloth net and tightly fixed to prevent snail escape. Using a micropipette containing $10 \mu \mathrm{L}$, the tested dose was gently applied once to the surface of the snail body inside the shell. Animals gained $10 \mu \mathrm{L}$ of distilled water was considered as control. A little water was added daily to each box to ensure the moisture needed for the snail's activity. The mortality percentages were recorded $48 \mathrm{~h}$ after exposure. The $\mathrm{LD}_{50}$ values for T. pisana snails were determined by the Probit analysis method (Finney 1971).

\section{Sub-lethal toxicity experiment}

In a separate series of experiments, sub-lethal doses of ABM (20\% and $\left.60 \% 48 \mathrm{~h}-\mathrm{LD}_{50}\right)$ were applied topically to T. pisana snails, as in the aforementioned procedure to examine the possible impacts of this biocide on the hepatopancreas of the animals and its biochemical alterations.

Three experimental groups of snails (30 animals in each group), were used in this study.

Group I (control): Untreated animals were considered as controls.

Group II: A single dose of $10 \mu \mathrm{l}$ of $20 \%$ ABM $-\mathrm{LD}_{50}$ (i.e., $0.21 \mu \mathrm{g} /$ snail) applied topically via injection into the shell cavity.

Group III: A single dose of $10 \mu \mathrm{l} 60 \%$ ABM -LD 50 (i.e., $0.63 \mu \mathrm{g} / \mathrm{snail}$ ) was received by the animal via injection into the shell cavity. 
The sub-lethal effects of $A B M$, on the survivors of snails that exposed to the sub-lethal doses, were studied on some snail biochemical attributes at 1, 3 and 7 days after treatment. Biochemical disturbances assessed by measuring the five enzymes activities; Glutathione-S-transferase (GST), $Y^{-}$ Glutamyl transferase ( $\mathrm{Y}-\mathrm{GT}$ ), Aspartate aminotransferase (AST), Alanine aminotransferase (ALT) and Lactate dehydrogenase (LDH) along with three energy reserves; lipids, glycogen and proteins.

\section{Sample preparation}

At the end of each time, the shells of nine randomly chosen survival snails from each group were taken off. Then the hepatopancreas were excised, rinsed with $0.9 \%$ ice-cold saline and weighed. The hepatopancreas was splitted into two portions; the first portion was taken for measuring glycogen and lipids content, whereas the second portion was homogenized in 10 volumes of ice-cold saline for $30 \mathrm{~s}$ and centrifuged at $5000 \mathrm{~g}$ for $20 \mathrm{~min}$ at $4{ }^{\circ} \mathrm{C}$. The supernatant was used to measure GST, $\mathrm{Y}$-GT, AST, ALT and LDH activities and total soluble proteins.

\section{Biochemical assays}

The glycogen content was assessed by the method of Van Hendel (1965). Total lipids were assessed according to Knight et al. (1972). Total soluble proteins were assessed by Lowry et al. (1951). Each biochemical assessment was determined six times. The values for glycogen, lipids and proteins were derived from standard curves plotted with known concentrations of glucose, soybean oil and bovine serum albumin, consecutively. All previous components were expressed as $\mathrm{mg} / \mathrm{g}$ tissue. Total energy reserves (kilojoules per gram ( $\mathrm{kJ} / \mathrm{g}$ )) were calculated according to Bowen et al. (1995): $1 \mathrm{~g}$ of protein, lipids or glycogen is equal to an energy of $17.3,38.9$ and $16.9 \mathrm{~kJ}$, respectively.

\section{Enzymatic measurements}

GST (EC 2.5.1.18) activity was determined based on Vessey and Boyer (1984) method. The enzyme activity was expressed as $\mu$ moles of CDNB conjugated/mg protein/min. $\gamma$-GT (EC 2.3.2.2) activity was measured by a commercial kit based on the method of Szasz (1974). Absorbance was recorded at 405 $\mathrm{nm}$ and the activity was expressed as U/L. Both AST (EC 2.6.1.1) and ALT (EC 2.6.1.2) activities were determined according to the method of Reitman and Frankel (1957) utilizing the Diamond Diagnostics kit (Diamond Co., Egypt) and their activities were expressed as U/L. LDH (EC 1.1.1.27) activity was measured by the method of McComb (1983) using Spectrum Diagnostic kit (Spectrum Co., Egypt). This enzyme activity was expressed as U/L. All enzymatic activities were determined six times.

\section{Data analysis}

All results were presented as a mean \pm standard error. The data from the biochemical responses test were analyzed to assure normality and uniformity of variance (Shapiro-Wilk and Levene's tests, respectively). Subsequently, the data were analyzed by analysis of variance (Two-way ANOVA) and the means were separated according to Student-Newman-Keuls test at a significance level of $p \leq 0.05$. The statistical analysis as performed with software Costat program, Version 2.6 (2002). 


\section{Results}

Impact of ABM on mortality of T. pisana snails

Following $48 \mathrm{~h}$ of topical application of T. pisana snails, the percentage mortalities of ABM treated snails are dose dependent and gradually increase with increasing dose (Table 1). No death was recorded in controls throughout the time of assay. ABM killed $100 \%$ of test snails at $10 \mu \mathrm{g} / \mathrm{snail}$. The results of Probit analysis shows that the $L_{50}$ value of $A B M$ was $1.048 \mu \mathrm{g} / \mathrm{snail}$.

Table 1

Lethal contact toxicity parameters of ABM against the land snail, Theba pisana

\begin{tabular}{|c|c|}
\hline Doses used ( $\mu \mathrm{g} / \mathrm{snail})$ & Mortality percentage \\
\hline 0.25 & $13.3 \pm 0.33$ \\
\hline 0.5 & $33.3 \pm 0.41$ \\
\hline 1 & $53.3 \pm 0.33$ \\
\hline 1.5 & $60.0 \pm 0.00$ \\
\hline 2 & $66.6 \pm 0.88$ \\
\hline 3 & $73.3 \pm 0.67$ \\
\hline 4 & $80.0 \pm 0.82$ \\
\hline 5 & $86.6 \pm 0.33$ \\
\hline 10 & $100 \pm 0.00$ \\
\hline Control & 0.0 \\
\hline $\operatorname{LD}_{50}(\mu \mathrm{g} / \mathrm{snail})$ & $1.048(1.21-0.897)$ \\
\hline Regression equation & $Y=-0.032+1.55 X$ \\
\hline Slope \pm Variance & $1.55 \pm 0.015$ \\
\hline$\chi^{2}(\mathrm{df})$ & $2.67(6)$ \\
\hline \multicolumn{2}{|c|}{ Each figure represents the mean percent mortality $\pm S E(n=3)$} \\
\hline
\end{tabular}

Effect of $A B M$ on the energy reserves of T. pisana snails

The results of energy reserves (lipids, glycogen and proteins) in survivors T. pisana snails after exposure to sub-lethal doses; $20 \%$ and $60 \% \mathrm{LD}_{50}$ of $\mathrm{ABM}$ are presented in Table 2 . 
Table 2

Total lipids, glycogen and total proteins $(\mathrm{mg} / \mathrm{g}$ fresh tissue, $\pm \mathrm{SE}$ ) in the hepatopancreas of survivors Theba pisana snails treated with sub-lethal doses of ABM after different times of exposure

\begin{tabular}{|c|c|c|c|c|c|c|}
\hline \multirow[t]{3}{*}{$\begin{array}{l}\text { Time of exposure } \\
\text { (days) }\end{array}$} & \multirow[t]{3}{*}{$\begin{array}{l}\text { Untreated } \\
\text { snails }\end{array}$} & \multicolumn{4}{|c|}{$\begin{array}{l}\text { Survivors from treated snails with sub-lethal } \\
\text { doses }\end{array}$} & \multirow[t]{3}{*}{ Mean } \\
\hline & & \multicolumn{2}{|l|}{$20 \% L_{50}$} & \multicolumn{2}{|l|}{$60 \% \mathrm{LD}_{50}$} & \\
\hline & & Mean \pm SE & $\begin{array}{l}\% \\
\text { control }\end{array}$ & Mean \pm SE & $\begin{array}{l}\% \\
\text { control }\end{array}$ & \\
\hline \multicolumn{7}{|l|}{ Total lipids } \\
\hline 1 & $101.6 \pm 0.81$ & $\begin{array}{l}86.4 \pm \\
0.41\end{array}$ & 85.01 & $\begin{array}{l}85.0 \pm \\
0.53\end{array}$ & 83.64 & 91.00 \\
\hline 3 & $111.8 \pm 0.64$ & $\begin{array}{l}82.9 \pm \\
0.31^{*}\end{array}$ & 74.14 & $\begin{array}{l}81.0 \pm \\
0.65^{\star}\end{array}$ & 72.47 & 91.90 \\
\hline 7 & $122.0 \pm 0.50$ & $\begin{array}{l}82.3 \pm \\
0.04^{*}\end{array}$ & 67.44 & $\begin{array}{l}78.7 \pm \\
0.80^{*}\end{array}$ & 64.51 & 94.30 \\
\hline Mean & 111.80 & 83.86 & & 81.56 & & \\
\hline \multicolumn{7}{|l|}{ Glycogen } \\
\hline 1 & $112.0 \pm 0.65$ & $\begin{array}{l}90.9 \pm \\
0.50^{*}\end{array}$ & 81.10 & $\begin{array}{l}88.6 \pm \\
0.37^{\star}\end{array}$ & 79.11 & 97.16 \\
\hline 3 & $113.1 \pm 0.26$ & $\begin{array}{l}88.1 \pm \\
0.03^{*}\end{array}$ & 77.86 & $\begin{array}{l}85.0 \pm \\
0.19^{*}\end{array}$ & 75.14 & 95.40 \\
\hline 7 & $113.9 \pm 1.75$ & $\begin{array}{l}83.0 \pm \\
0.31^{*}\end{array}$ & 72.88 & $\begin{array}{l}81.4 \pm \\
0.48^{\star}\end{array}$ & 71.50 & 92.76 \\
\hline Mean & 113.00 & 87.33 & & 85.00 & & \\
\hline \multicolumn{7}{|l|}{ Total proteins } \\
\hline 1 & $75.8 \pm 0.10$ & $\begin{array}{l}70.2 \pm \\
0.10\end{array}$ & 92.67 & $\begin{array}{l}88.2 \pm \\
0.14^{*}\end{array}$ & 116.42 & 78.06 \\
\hline 3 & $77.0 \pm 0.15$ & $\begin{array}{l}75.8 \pm \\
0.41\end{array}$ & 98.44 & $\begin{array}{l}82.7 \pm \\
0.29\end{array}$ & 107.36 & 78.50 \\
\hline 7 & $78.2 \pm 0.11$ & $\begin{array}{l}67.8 \pm \\
0.73^{*}\end{array}$ & 86.67 & $\begin{array}{l}90.6 \pm \\
0.19^{*}\end{array}$ & 115.85 & 78.86 \\
\hline Mean & 77.00 & 71.26 & & 87.16 & & \\
\hline
\end{tabular}

Table 2 shows that total lipids were significantly reduced in the survivors of treated snails after 3 and 7 days' exposure to the tested sub-lethal doses of ABM. This decrease was highest at 7 days, while the 
lowest was recorded at 1 day after treatment. The data was also shown that this reduction was clearly dose- and time- dependent. However, non-significant reduction in total lipids was observed among ABMtreated snails after 1 day post treatment when compared with the control.

As for the glycogen contents, ABM was caused a significant decrease at all times of exposure compared to controls. Percent reductions in glycogen after $20 \% \mathrm{LD}_{50}$ ABM treatment were 81.10, 77.86 and 72.00, while were $79.11,75.14$ and 71.50 after $60 \% L_{50}$ at 1,3 , and 7 days of exposure, consecutively. Generally, these reductions appeared to be obviously dose- and time- dependent, where the marked reduction was significantly higher in the survivor's snails treated with the two sub-lethal doses after 7 days (Table 2).

The response of total proteins in ABM-treated snails was inconsistent compared to control snails. In the survivor's snails exposed to $20 \% L_{50} A B M$, total proteins were non-significantly lower than of the control (92.67\%), however, significant higher total proteins were observed in $60 \% \mathrm{LD}_{50}$ treated snails $(116.42 \%)$ after 1 day. After 3 days of exposure, there were non-significant decreases and increases in total proteins among survivor's snails exposed to $A B M$ at $20 \%$ and $60 \% L_{50}$, respectively. After 7 days of exposure to $20 \% \mathrm{LD}_{50}$, a marked reduction in total proteins in the survivors treated snails was recorded, while a significant increase in total proteins was found after exposure to $60 \% \mathrm{LD}_{50} \mathrm{ABM}$ (Table 2).

Overall, significant reductions in total energy reserves in the survivors T. pisana treated with the sub-lethal doses of ABM at all exposure times were observed (Table 3).

Table 3

Total energy reserves $(\mathrm{kJ} / \mathrm{g} \pm \mathrm{SE})$ in untreated and survivors from treated land snail, Theba pisana with sub-lethal doses of ABM following various time intervals

\begin{tabular}{|c|c|c|c|c|c|c|}
\hline \multirow[t]{3}{*}{$\begin{array}{l}\text { Exposure time } \\
\text { (days) }\end{array}$} & \multirow[t]{3}{*}{$\begin{array}{l}\text { Untreated } \\
\text { snails }\end{array}$} & \multicolumn{4}{|c|}{$\begin{array}{l}\text { Survivors from treated snails with sub-lethal } \\
\text { doses }\end{array}$} & \multirow[t]{3}{*}{ Mean } \\
\hline & & \multicolumn{2}{|l|}{$20 \% L_{50}$} & \multicolumn{2}{|l|}{$60 \% L_{50}$} & \\
\hline & & Mean \pm SE & $\begin{array}{l}\% \\
\text { control }\end{array}$ & Mean \pm SE & $\begin{array}{l}\% \\
\text { control }\end{array}$ & \\
\hline 1 & $7.16 \pm 0.48$ & $\begin{array}{l}6.11 \pm \\
0.36^{*}\end{array}$ & 85.38 & $\begin{array}{l}6.33 \pm \\
0.47^{*}\end{array}$ & 88.45 & 6.53 \\
\hline 3 & $7.59 \pm 0.12$ & $\begin{array}{l}6.02 \pm \\
0.59^{*}\end{array}$ & 79.34 & $\begin{array}{l}6.02 \pm \\
0.24^{*}\end{array}$ & 79.26 & 6.54 \\
\hline 7 & $8.02 \pm 0.45$ & $\begin{array}{l}5.78 \pm \\
0.28^{\star}\end{array}$ & 71.99 & $\begin{array}{l}6.01 \pm \\
0.43^{*}\end{array}$ & 74.84 & 6.60 \\
\hline Mean & 7.59 & 5.97 & & 6.12 & & \\
\hline
\end{tabular}




\section{Effect of ABM on the enzymes activities of T. pisana snails}

Different patterns of responses were detected in the enzymes activities (GST, $Y$-GT, LDH, AST and ALT) in the survivors T. pisana exposed to sub-lethal doses of ABM (Fig. 1-5).

The GST activities in the survivor's snails treated with $20 \% \mathrm{LD}_{50}$ ABM were increased without significant differences when compared to the controls after 1 and 3 days' exposure, however the GST activity significantly increased after 7 days. Significant differences were also observed in $60 \% L_{50}$ survivors of treated snails after all times of exposure. These significant increases were $135.19 \%$ in the $20 \% \mathrm{LD}_{50}$ treatment after 7 days and 153.46, 165.49 and $152.63 \%$ in the $60 \% L_{50}$ treatment after 1,3 and 7 days (Fig. 1).

Significant differences were found in the survivors treated and untreated snails in the activity of $y-G T$. The activity of $\mathrm{Y}-\mathrm{GT}$ was clearly induced by exposure to $A B M$ at 20 and $60 \% \mathrm{LD}_{50}$ compared to controls. (Fig. 2). This increase of enzyme activity was dose- dependent but not time-dependent.

LDH activity in the survivor's snails treated with either 20 or $60 \% \mathrm{LD}_{50} \mathrm{ABM}$ was higher than the enzyme activity of untreated snails (Fig. 3).

As shown in Fig. 4, the activity of AST in the survivor's snails was significantly decreased by $87.39 \%$ in the $20 \% L_{50}$ ABM after 7 days and its activity was also decreased after 1 and 3 days of exposure without significant differences. In case of $60 \% L_{50} A B M$, significant decreases in the activity of AST in the survivor's snails were recorded with values of $90.26,86.89$ and $84.49 \%$ after 1,3 and 7 days, respectively. Decreases of the activity were dose- and time-dependent.

Figure 5 shows that, compared to the control, there was no significant decrease in ALT activity in the survivor's snails at 1 day after treatment with each of sub-lethal dose. However, after 3 and 7 days, both sub-lethal doses caused significant decreased in ALT activity compared with that of the control.

\section{Discussion}

In recent decades, the impact of pesticides on the environment is becoming a major problem worldwide. The continuous use of pesticides is burden on the soil ecosystem and causes deterioration in its health, along with potential consequences on soil-inhabiting invertebrates, which are indicators of soil quality. Therefore, more and more detailed ecotoxicological data are needed to better understand its actual threats as pesticide use is unlikely diminish in the near future (Gunstone et al. 2021). Up to date, the ecotoxicological impacts of avermectins against land gastropods have been rarely studied. This prompted us to study the lethal and sub-lethal toxicity of ABM against T. pisana snails.

In current study, the acute toxicity data obviously showed that ABM has lethal action against T. pisana snails. Regardless to the route of administration (contact or dietary exposure), the obtained data are in a good agreement with previous results in which ABM has lethal toxic action against different land 
gastropod species; T. pisana (Gad et al. 2016; Radwan 2016), Massylaea vermiculata (Syn: Eobania vermiculata) (Gabr et al. 2006; Kandil et al. 2014; Abdelgalil et al. 2018; Hussein and Sabry 2019), Monacha obstructa (Gabr et al. 2006; Kandil et al. 2014) and Deroceras reticulatum (Airey et al. 1989). On the other hand, $A B M$ at $0.2 \%$ spray has high potential usefulness in protecting rape seedlings from the slug, Arion lusitanicus, but non-lethal to the animal (Kozlowski et al. 2010).

It is well known that pesticide sub-lethal toxicity is measured using molecular and cellular endpoints, which are also used to assess modes of action, metabolic pathways and detoxification mechanisms (van der Oost et al. 2003; Moreira et al. 2020). The digestive gland (hepatopancreas) is the main target for the toxic effects of xenobiotics, such as pesticides, that play crucial role in the accumulation, metabolism and detoxification as well as the biosynthesis of energetic macromolecules for different essential functions in molluscs (Dallinger et al. 2002). Therefore, changes in the digestive gland biochemical parameters as biomarkers due to the sub-lethal doses of the compound intoxication have been widely utilized as an indicator to assess the toxic action of xenobiotics on snails. In order to get insights into sub-lethal effects on the survivor's snails that exposed to $20 \%$ and $60 \%$ LD50 ABM doses in our study, the energy reserves (glycogen, lipids and proteins) and enzyme activities (GST, $\mathrm{Y}-\mathrm{GT}, \mathrm{LDH}, \mathrm{AST}$ and ALT) as usual biomarkers were assessed in T. pisana snails.

The role of biomolecules include lipids, carbohydrates and proteins are critical in triggering different types of biochemical, physiological and behavioral responses in living organisms (Yazdani et al. 2013). These bioenergetics parameters have been suggested as useful biomarker to detect the deleterious effects and toxicological mechanisms induced by environmental pollutants. Few studies have been done to evaluate the adverse effects of pesticides including ABM on the energy reserves of land snails (Radwan et al. 2008; Radwan and Mohamed 2013; Kandil et al. 2014). Therefore, this negative impact on the energy reserves as a result of pesticide exposure needs more investigations.

Lipids play a very important role in the normal functioning of cells. They not only act as a highly reduced form of energy storage, but also play a close role in the structure of cell membranes and organelles found in cells (Kandil et al. 2014). In this investigation, total lipids were significantly decreased in the survivors of ABM- treated snails with sub-lethal doses. The decreased level of lipids after treatment may be ascribed to the impairment of lipid biosynthesis, metabolism and/or utilization as an energy source for surviving under stressful conditions (Radwan et al. 2008; Shaurub and Aziz 2015). In agreement with our results, Megahed et al. (2013) noticed that total lipids significantly decreased in hemolymph of treated 4th instar larvae of Spodoptera littoralis with ABM, emamectin and spinosad at 24, 48 and $72 \mathrm{~h}$.

Glycogen is an important component of living cells and a source of energy for animals. In our study, there were significant decreases in the glycogen contents of the survivors of T. pisana snails throughout the ABM-treatment periods. This depletion indicating animals are utilizing their energy reserves to cope with toxic stress (Tendulkar and Kulkarni 2012) or for increased rate of glycogen breakdown "glycogenolysis" (Ansaldo et al. 2006). The aforementioned findings are in coincidence with those of Riaz et al. (2019) who showed that the glycogen contents were significantly deceased in 4th and 6th larval instars of two 
geographically distinct Trogoderma granarium field populations exposed to $\mathrm{LC}_{20}$ of $\mathrm{ABM}$, emamectin and spinosad alone and in various combinations.

Protein is an important organic constituent of animal tissue. It plays an important role in energy metabolism. Protein regulates the process of interaction between intra and extra cellular media (Remia et al. 2008). In the present study, decreases in total proteins of the survivor's snails exposed to $20 \% L_{50}$ of ABM were observed, however, total proteins were increased in the survivor's snails exposed to $60 \% \mathrm{LD}_{50}$ compared to the control. The obtained data clearly indicate that the changes in the content of proteins depends on the sub-lethal dose used. The increase in total proteins could be elucidated by increased the protein synthesis of animal in response to this stress. On the other hand, the decrease in total proteins under pesticide exposure could be due to the formation of lipoproteins usage to repair the damage of cells and/or for straight usage by cells for energy demands (Padmaja and Rao 1994; Radwan et al. 2008).

Our data confirmed the results of Kandil et al. (2014), where total protein levels in, M. vermiculata and Monacha obstructa were increased when the snails exposed to $A B M$ as a contact poison. A single dose of $0.25 \mathrm{LD}_{50} \mathrm{ABM}$ significantly decrease the total proteins in male albino rats (El- Shafey et al. 2011). Moreover, Al-Kahtani (2011) showed that total protein levels in various organs and/or tissues in the tilapia fish (Oreochromis niloticus) decreased after exposure to $20 \mu \mathrm{g} / \mathrm{L} \mathrm{ABM}$ for up to $96 \mathrm{~h}$.

The GST enzyme is a part of the detoxification pathway II via conjugation of xenobiotics and/or endogenous compounds with glutathione (GSH) (van der Oost et al. 2003). Our data clearly indicate that ABM induced increment in GST activity of the survivors exposed snails throughout the experimental period. These data suggest that the elevation of antioxidant protection is associated with increased production of oxygen-free radicals, which can enhance antioxidant activity to prevent oxidative stress and protect cells from damage (Elia et al. 2007). An increase in GST activity is also detected in response to pollutants e.g., pesticides, resulting from their detoxification via the formation of glutathione conjugates (Saravana Bhavan and Geraldine 2000). Similar to our investigation, the activity of this enzyme was increased in the same snail species treated with 1/20 LC ${ }_{50}$ ABM for 2 weeks of exposure (El-Gendy et al. 2019). Enhancement of GST activity in the snail, Physa acuta treated with ABM during the periods of 12$48 \mathrm{~h}$ exposure was also observed (Ma et al. 2014).

Among the enzymes commonly used to assess hepatic function, $\mathrm{Y}-\mathrm{GT}$ is considered a reliable biomarker that is closely associated with the identification of damage caused by oxidative stress (0"zer et al. 2008). This enzyme plays a central role in the re-synthesis of glutathione. In addition, Lee et al. (2004) suggested that it is inversely proportional to the levels of many other antioxidants. It is conceivable that the prooxidation effect of $Y$-GT activity is usually balanced by its established role in facilitating the uptake of precursors by the cell to promote the re-synthesis of GSH. Thereby allowing the rebuilding of cellular antioxidant defenses (Banerjee et a1. 1999). In the current study, a significant increase in $\mathrm{Y}$-GT activity in the survivor's snails was noticed due to their treatment with the two sub-lethal of ABM doses. This enzyme elevation may be attributed to the significant tissue injury provoked by pesticides, even at low 
doses. These results are in line with Khaldoun-Oularbi et al. (2017) who recorded that ABM caused an increase in the activity of $\mathrm{Y}-\mathrm{GT}$ in male and female rats, Rattus norvegicus at 14, 28 and 42 days.

Likewise, there were significant increases in Y-GT activity after the isolated rat hepatocytes exposed to 10 and $100 \mu \mathrm{M}$ of $\mathrm{ABM}$, for 30,60 and $120 \mathrm{~min}$ as compared to respective control (El-Shenawy 2010).

One of the ways for assessing the integrity of cell membranes is to determine the activity of LDH, an enzyme present in all organs and tissues (Kending and Tarloff 2007). LDH is an enzyme shared in the induction of anaerobic metabolism, and its assessment can be used for understanding the energy production in organisms that can occur either aerobically or anaerobically (Müller et al. 2012). In our study, ABM at sub-lethal doses caused a marked increase in the activity of LDH of the treated survivors snails, which indicates its ability to change the permeability of cell membranes, causing cell death, since an increased leakage of LDH into the serum indicates membrane degradation (Amin and Hamza 2005). Thus, it is considered a good biomarker for cell and membrane damage. The increasing energy demand of the organism during pesticide stress is achieved by using carbohydrates as the main and immediate source of energy (Umminger 1977). This may be accompanied by increased LHD levels as result of the role of $L D H$ in converting the pyruvate into lactate. Previous studies recorded the enhancement of LDH activity in ABM-treated rats (El-Shenawy 2010; Mossa et al. 2017). However, ABM recorded no significant decrease in the LDH activity of hamsters uninfected and infected with Schistosoma mansoni (El-Kabbany et al. 2017).

Among the hepatocellular injury markers, transaminases enzymes ALT and AST are probably the most commonly used in both clinical diagnosis and research involving liver damage. Both enzymes are not only found in liver cells, but also in many body organs. Of the two, ALT is predominantly present in the cytosol of the liver and is present elsewhere at low concentrations and is therefore thought to be more specific for hepatic damage. Our results indicated that the activity of AST and ALT decreased in the survivor's snails treated with sub-lethal doses of ABM. The decrease in AST and ALT could indicate tissue damage in the snails as a result of the presence of $A B M$ in their tissues. Thus, biochemical disorders and lesions of tissue and cellular functions can occur when the activity of both enzymes are deviate from the normal range (Radwan et al. 1992). In the literature, the effect of ABM on the AST and ALT activities fluctuate among activation, inhibition, and no effect. Previous studies reported that the activity of AST decreased in treated peach fruit fly, Bactrocera zonata than the untreated ones after treatment with ABM (Biomectin $\AA$ ) and spinosad (Tracer ${ }^{\circledR}$ ), while the activity of ALT increased after treatment with Biomectin ${ }^{\circledR}$ and decreased after treatment with Tracer ${ }^{\circledR}$ compared to controls (Farag et al. 2017). Enhancement in ALT and AST activities were recorded in M. vermiculata and T. pisana after treatment with $0.1,0.2$ and 0.5 of $L_{50} A B M$ for 24 and $72 \mathrm{~h}$ (Hamza et al. 2020). No significant differences in the AST and ALT activities after treatment of hamsters uninfected and infected with Schistosoma mansoni with ABM were observed (El-Kabbany et al. 2017).

\section{Conclusion}


In this study, a prominent lethal and sub-lethal toxic effect of ABM on the land snail, T. pisana was detected, for energy reserves (glycogen, lipids and proteins) as well as for enzymatic activities (GST, Y-GT, LDH, AST and ALT) in the digestive glands of survivor's snails at doses of 20 and $60 \% L_{50}$. The apparent changes of these biochemical parameters in the treated snails indicate that ABM may have cytotoxic and biochemical impairment and thus may be considered as good biomarkers of toxicity. All the biochemical changes that occur in ABM-treated snails in our study may be due to the reactive oxygen species (ROS) formation that leads to oxidative damage in several non-target organisms such as aquatic animals (Hong et al. 2020), terrestrial snails (El-Gendy et al. 2019), and rats (Khaldoun - Oularbi et al. 2017). In fact, changes in the tested biochemical parameters have the potential to influence on the other biological disturbances such as mucus production, movement, feeding, growth and reproduction. Our results confirmed previous studies that the land snail, T. pisana can be used as a bioindicator of ABM exposure. These results also confirm the importance of evaluating effects by measuring a set of biomarkers to understand the biochemical mechanisms involved in the physiology of snails in response to ABM. Further studies on other avermectin members are underway in our laboratory to verify their ecotoxicological profile in land snails.

\section{Declarations}

\section{Ethics approval and consent to participate}

The experiments were carried out according to the guidelines for animal care and handling, with the approval of the Animal Ethics Committee of Alexandria University, Alexandria, Egypt.

\section{Consent for publication}

Not applicable

\section{Availability of data and materials}

The datasets used and/or analysed during the current study are available from the corresponding author on reasonable request.

\section{Competing interests}

The authors declare that they have no competing interests

\section{Funding}

There is no received any funding sources for this article.

\section{Authors' contributions}

MAR: conceptualized work, did formal analysis and investigation, wrote the first draft of manuscript, provided editorial comments and suggestions for draft manuscript, Resources and 
Supervision. AFG: provided methodology, did formal analysis and investigation and wrote the first draft of manuscript. All authors read and approved the manuscript.

\section{References}

1. Abdelgalil GM, Abou-Elnasr HS, Khalil MS, Abouhamer MS, Osman AM, Abdallah EAM (2018) Molluscicidal toxicity of abamectin against Eobania vermiculata and Theba pisana in vivo and the estimation of GABA-Transaminase activity by HPLC. J Biopest 11:161-168

2. Airey WJ, Henderson IF, Pickett JA, Scott GC, Stephenson JW, Woodcock CM (1989) Novel chemical approaches to mollusc control. p. 301-307. In: Slugs and Snails in World Agriculture, Henderson, I. (Ed.). Monograph. British Crop Protection Council, No. 41, 422 pp

3. Al-Kahtani MA (2011) Effect of an insecticide abamectin on some biochemical characteristics of Tilapia fish (Oreochromis niloticus). American Journal of Agricultural Biological Sciences 6:62-68

4. Amin A, Hamza AA (2005) Oxidative stress mediates drug-induced hepatotoxicity in rats: a possible role of DNA fragmentation. Toxicology 208:367-375

5. Ansaldo M, Nahabedian DE, Holmes-Brown E, Agote M, Ansay CV, Verrengia Guerrero NR, Wider EA (2006) Potential use of glycogen level as biomarker of chemical stress in Biomphalaria glabrata. Toxicology 224:119-217

6. Agricultural Pesticides Committee APC (2021) The website of Agricultural Pesticides Committee (APC), the Ministry of Agriculture and Land Reclamation, Egypt. http://www.apc.gov.eg Accessed June 5, 2021

7. Banerjee BD, Seth V, Bhattacharya A, Pasha ST, Chakraborty AK (1999) Biochemical effects of some pesticides on lipid peroxidation and free-radical scavengers. Toxicol Lett 107:33-47

8. Bloomquist JR (2003) Chloride channels as tools for developing selective insecticides. Arch Insect Biochem Physiol 54:145-156

9. Bowen SH, Lutz EV, Ahlgren MO (1995) Dietary protein and energy as determinants of food quality: Trophic strategies compared. Ecology 76, 899-907, In: TTS, Hoar, W.S., Randall DJ, Brett, J.R. (Eds.), Physiological Energetics. Academic Press. New York, USA. pp. 279-352

10. Costat program (2002) Microcomputer program analysis. CoHort software, Version 2.6, Monterey, CA, USA

11. Dallinger R, Berger B, Triebskorn R, Kohler H (2002) Soil Biology and Ecotoxicology. In: Barker GM (ed) The Biology of Terrestrial Molluscs. CAB International, Oxon, pp 489-525

12. de Vaufleury A, Coeurdassier M, Pandard P, Scheifler R, Lovy C, Crini N, Badot PM (2006) How terrestrial snails can be used in risk assessment of soils. Environ Toxicol Chem 25:797-806

13. El-Gendy KS, Radwan MA, Gad AF, Khamis AE, Eshra EH (2019) Use of multiple endpoints to investigate the ecotoxicological effects of abamectin and thiamethoxam on Theba pisana snails. Ecotoxicol Environ Saf 167:242-249 
14. Elia AC, Galarini R, Dorra AJM, Taticchi MI (2007) Heavy metal contamination and antioxidant response of a freshwater bryozoan (Lophopus crystallinus Pall., Phylactolaemata). Ecotoxicol Environ Saf 66:188-194

15. El-Kabbany Al, Hamza RS, Ismail SM, Ghaled KI (2017) Effect of Abamectin on Biochemical, Immunological and Histological Parameters of Hamster Infected with Schistosoma mansoni. International Journal of Chinese Medicine 1:92-101

16. El-Shafey AAM, Seliem MME, El-Mahrouky F, Gabr WM, Kandil RA (2011) Some Physiological and Biochemical Effects of Oshar Extract and Abamectin Biocide on Male Albino Rats. Journal of American Science 7:254-261

17. El-Shenawy NS (2010) Effects of insecticides fenitrothion, endosulfan and abamectin on antioxidant parameters of isolated rat hepatocytes. Toxicol In Vitro 24:1148-1157

18. Erzen NK, Kolar L, Flajs VC, Kuzner J, Marc I, Pogacnik (2005) Degradation of abamectin and doramectin on sheep grazed pasture. Ecotoxicology 14:627-635

19. Farag SRM, Morsi GMA, Mohamed SAE (2017) Insecticidal activity and biochemical effects of two bioinsecticidal on Bactrocera zonata (SAUNDERS) (Diptera: Tephritidae). Egypt Acad J Biol Sci 10:17-23

20. Finney DJ (1971) Probit Analysis, 3rd Edition, Cambridge University Press, Cambridge, U.K

21. Fisher MH, Mrozik M (1989) Ivermectin and Abamectin. Springer Verlag, New York, pp 1-23

22. Gabr WM, Youssef AS, Khidr FK (2006) Molluscicidal effect of certain compounds against two land snail species, Monacha obstructa and Eobania vermiculata under laboratory and field conditions. Journal of Agricultural Research 84:43-50

23. Gad AF, Radwan MA, EL-Gendy KS, Eshra EH, Seehy MA, Khamis A (2016) Genotoxic potential of some pollutants in Theba pisana snails using the micronucleus test. International Journal of Zoological Investigations 2:197-205

24. Gunstone T, Cornelisse T, Klein K, Dubey A, Donley N (2021) Pesticides and Soil Invertebrates: A Hazard Assessment. Front Environ Sci 9:643847. doi:10.3389/fenvs.2021.643847

25. Halley BA, Jacob TA, Lu AYH (1989) The environmental impact of the use of ivermectin: Environmental effects and fate. Chemosphere 18:1543-1563

26. Hamza SA, Abdelgalil GM, Abdallah EAM, Kassem FA, Asran AA (2020) Effects of abamectin on glutamate decarboxylase, alanine aminotransferase and aspartate aminotransferase of land snails. International Journal of Zoological Investigations 6:311-320

27. Hamza-Chaffai A (2014) Usefulness of bioindicators and biomarkers in pollution biomonitoring. International Journal of Biotechnology for Wellness Industries 3:19-26

28. Horowitz AR, Ishaaya I (2004) Biorational Insecticides - Mechanisms, Selectivity and Importance in Pest Management. In: Horowitz AR, Ishaaya I (eds) Insect Pest Management. Springer-Verlag, Berlin Heidelberg, pp 1-28 
29. Hussein MA, Sabry AKH (2019) Assessment of some new pesticides as molluscicides against the adult and eggs of chocolate banded snail, Eobania vermiculata. Bull Natl Res Cent 43:75. https://doi.org/10.1186/s42269-019-0118-6

30. Jansson RK, Dybas RA (1998) Avermectins: Biochemical Mode of Action, Biological Activity and Agricultural Importance. In: Ishaaya I, Degheele D (eds) Insecticides with Novel Modes of Action. Applied Agriculture. Springer, Berlin. https://doi.org/10.1007/978-3-662-03565-8_9

31. Kandil MA, El-Deeb HI, Eweis EA, Gabr WM, Mobarak SA (2014) Effect of acetylsalicylic acid on the physiological role of mucus gland of land snail species. Egypt $J$ Agric Res 92:53-73

32. Kending DM, Tarloff JB (2007) Inactivation of lactate dehydrogenase by several chemicals: Implications for in vitro toxicology studies. Toxicology In Vitro 21:125-132

33. Khaldoun-Oularbi H, Nacira Z, Camille R, Hadjer A, Mohamed RE, Nadia D (2017) Vertimec ${ }^{\circledR}$ mediates plasma biochemical changes and histopathological damage in the kidney of rats (Rattus norvegicus). Journal of International Scientific Publications 5:622-630

34. Knight JA, Rawle JM, Anderson S (1972) Chemical basis of sulfo-phospho-vanillin reaction for estimating total serum lipids. Clin Chem 18:199-202

35. Kozlowski J, Kałuski T, Jaskulska M, Kozłowska M (2010) Initial evaluation of the effectiveness of selected active substances in reducing damage to rape plants caused by Arion lusitanicus (Gastropoda, Pulmonata, Arionidae). Journal of Plant Protection Research 50:520-526

36. Lee DH, Blomhoff R, Jacobs DR Jr (2004) Is serum gamma glutamyl transferase a marker of oxidative stress? Free Radic Res 38:535-539

37. Lowry OH, Rasebrough NJ, Farr AL, Randall RJ (1951) Protein measurement with the folin phenol reagent. J Biol Chem 193:265-275

38. Lumaret JP, Errouissi F, Floate K, Römbke J, Wardhaugh K (2012) A review on the toxicity and nontarget effects of macrocyclic lactones in terrestrial and aquatic environments. Curr Pharm Biotechnol 13:1004-1060

39. Ma J, Zhou C, Li Y, Li X (2014) Biochemical responses to the toxicity of the biocide abamectin on the fresh water snail Physa acuta. Ecotoxicol Environ Saf 101:31-35

40. Madejón P, Arrébola J, Madejón E, Burgos P, López-Garrido R, Cárcaba A, Cabrera F, Murillo JM (2013) The snail Theba pisana as an indicator of soil contamination by trace elements: potential exposure for animals and humans. J Sci Food Agric 93:2259-2266

41. McComb EB (1983) The measurement of LDH. In: Homburger, H.A., Skokie, I.L. (eds) Clinical and Analytic Concepts in Enzymology, College of American Pathologist, pp 157-171

42. Megahed MMM, El-Tawil MF, El-Bamby MMM, Abouamer WL (2013) Biochemical effects of certain bioinsecticides on cotton leafworm, Spodoptera littoralis (Boisd.) (Lepidoptera: Noctuidae). Res J Agric Biol Sci 9:308-317

43. Moreira RA, de Araujo GS, Silva ARRG, Daam MA, Rocha O, Soares AMVM, Loureiro S (2020) Effects of abamectin-based and difenoconazole-based formulations and their mixtures in Daphnia magna: a multiple endpoint approach. Ecotoxicology 29:1486-1499 
44. Müller M, Mentel M, van Hellemond JJ, Henze K, Woehle C, Gould SB, Yu RY, van der Giezen M, Tielens AGM, Martin WF (2012) Biochemistry and evolution of anaerobic energy metabolism in eukaryotes. Microbiol Mol Biol Rev 76:444-495

45. Nicolai A, Ansart A (2017) Conservation at a slow pace: terrestrial gastropods facing fast-changing climate. Conservation Physiology 5(1):cox007. 10.1093/conphys/cox007

46. O"zer S, Ayfer T, G"ulden O, Sule C, Gazi C, Nursal G, G“oksel S (2008) Protective effect of resveratrol against naphthalene-induced oxidative stress in mice. Ecotoxicol Environ 71:301-308

47. Özkara A, Akyıl D, Konuk M (2016) Pesticides, Environmental Pollution and Health. In: Environmental Health Risk-Hazardous Factors to Living Species, Larramendy ML, Soloneski S (Eds), IntechOpen, DOI: 10.5772/63094

48. Padmaja RJ, Rao MB (1994) Effect of an organochlorine and three organophosphate pesticides on glucose, glycogen, lipid and protein contents in tissues of the freshwater snail, Bellamya dissimilis (Müller). Bull Environ Contam Toxicol 53:142-148

49. Pitterna T, Cassayre J, Hüter OF, Jung PMJ, Maienfisch P, Kessabi FM, Cary I (2009) New ventures in the chemistry of avermectins. Bioorg Med Chem 17:4085-4095

50. Radwan MA (2016) Comparative toxic effects of some pesticides with different modes of action against the land snail, Theba pisana. International Journal of Zoological Investigations 2:170-176

51. Radwan MA, El-Gendy KS, Gad AF (2010) Biomarkers of oxidative stress in the land snail, Theba pisana for assessing ecotoxicological effects of urban metal pollution. Chemosphere 79:40-46

52. Radwan MA, El-Gendy KS, Gad AF (2020) Biomarker responses in terrestrial gastropods exposed to pollutants: A comprehensive review. Chemosphere 257:127218

53. Radwan MA, El-Wakil HB, Osman KA (1992) Toxicity and biochemical impact of certain oxime carbamate pesticides against terrestrial snail, Theba pisana (Müller). Journal of Environmental Science Health Part B: Pesticides Food Contaminants Agricultural Wastes 27:759-773

54. Radwan MA, Essawy AE, Abdelmeguied NE, Hamed SS, Ahmed AE (2008) Biochemical and histochemical studies on the digestive gland of Eobania vermiculata snails treated with carbamate pesticides. Pestic Bioch Physiol 90:154-167

55. Radwan MA, Mohamed MS (2013) Imidacloprid induced alterations in enzyme activities and energy reserves of the land snail, Helix aspersa. Ecotoxicol Environ Saf 95:91-97

56. Regoli F, Gorbi S, Fattorini D, Tedesco S, Notti A, Machella N, Bocchetti R, Benedetti M, Piva F (2006) Use of the land snail Helix aspersa as sentinel organism for monitoring ecotoxicologic effects of urban pollution: an integrated approach. Environ Health Persp 114:63-69

57. Reitman S, Frankel S (1957) A colorimetric method for the determination of serum glutamic oxalacetic and glutamic pyruvic transaminases. Am J Clin Pathol 28:56-63

58. Remia KM, Logaswamy S, Logankumar K, Rajmohan D (2008) Effect of an insecticides (Monocrotophos) on some biochemical constituents of the fish Tilipia Mossambica. Poll Res 27:523-526 
59. Riaz T, Shakoori FR, Mansoor H, Khan S, Saleem MA (2019) Efficacy of mixture of pesticides on the mortality and energy reserves of a stored grain pest Trogoderma granarium Everts. Pakistan Journal of Zoology 51:2297-2309

60. Sánchez-Bayo F (2011) Impacts of agricultural pesticides on terrestrial ecosystems. Chapter 4. In: van den Brink PJ, Mann RM (eds) Ecological Impacts of Toxic Chemicals, Sánchez-Bayo F. Bentham Science Publishers Ltd, pp 63-87

61. Saravana Bhavan P, Geraldine P (2000) Histopathology of the hepatopancreas gills of the prawn, Macrobrachium malcolmsonii exposed to endosulfan. Aquat Toxicol 50:331-339

62. Sharma A, Kumar V, Shahzad B, Tanveer M, Sidhu GPS, Handa N, Kohli SK, Yadav P, Bali AS, Parihar RD, Dar OI, Singh K, Jasrotia S, Bakshi P, Ramakrishnan M, Kumar S, Bhardwaj R, Thukral AK (2019) Worldwide pesticide usage and its impacts on ecosystem. SN Appl Sci 1:1-16. https://doi.org/10.1007/s42452-019-1485-1

63. Shaurub ESH, El-Aziz NMA (2015) Biochemical effects of lambda-cyhalothrin and lufenuron on Culex pipiens L. (Diptera: Culicidae). Int J Mosq Res 2:122-126

64. Szasz G (1974) Y-Glutamyl transpeptidase. In: Bergmeyer H-U (ed) Methods of Enzymatic Analysis, 2nd edn. Academic Press, New York, pp 715-720

65. Tendulkar M, Kulkarni A (2012) Cypermethrin-induced toxic effect on glycogen metabolism in estuarine clam, Marcia opima (Gmelin, 1791) of Ratnagiri Coast, Maharashtra. Journal of Toxicology. Volume 2012 |Article ID 576804 | https://doi.org/10.1155/2012/576804

66. Umminger BL (1977) Relation of whole blood sugar concentrations in vertebrates to standard metabolic rate. Compar Biochem Physiol 56:457-460

67. Van der Oost R, Beyer J, Vermeulen NPE (2003) Fish bioaccumulation and biomarkers in environmental risk assessment: a review. Environ Toxicol Pharmacol 13:57-149

68. Van Handel E (1965) Estimation of glycogen in small amount of tissue. Anal Biochem 11:256-265

69. Vessey DA, Boyer TD (1984) Differential activation and inhibition ofdifferent forms of rat liver glutathione S-transferase by the herbi-cides 2,4-dichloro phenoxy acetate (2,4-D) and 2,4,S trichlorophenoxy acetate (2,4,S-T). Toxicol Appl Pharmacol 73:492-499

70. Yazdani E, Sendi JJ, Aliakbar A, Senthil-Nathan S (2013) Effect of Lavandula angustifolia essential oil against lesser mulberry pyralid Glyphodes pyloalis Walker (Lep: Pyralidae) and identification of its major derivatives. Pestic Biochem Physiol 107:250-257

\section{Figures}




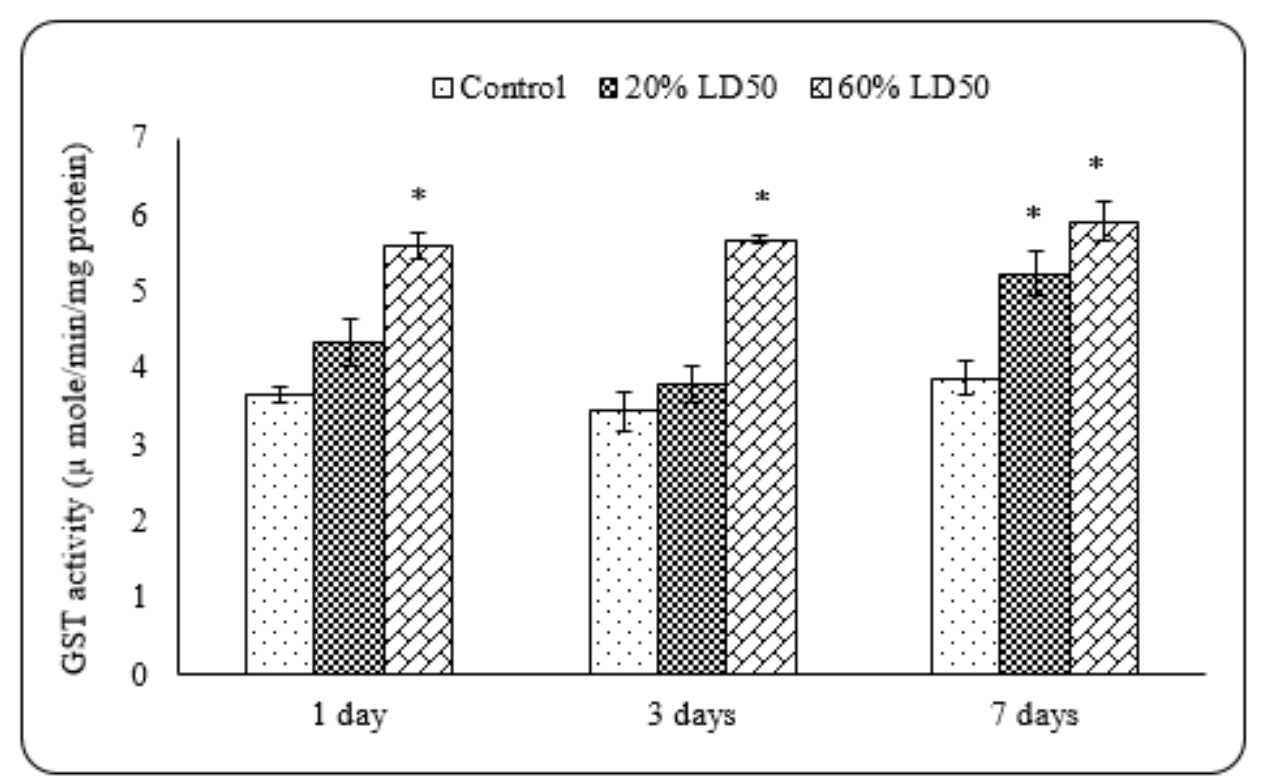

\section{Figure 1}

Glutathione-S-transferase (GST) activity in the survivors of Theba pisana treated with 20 and $60 \%$ LD50 $A B M$, together with their controls, for various time intervals. Bar represents mean $(n=3)$ and vertical line represents the standard error (SE). The star indicates a significant difference from the control $(p \leq 0.05)$.

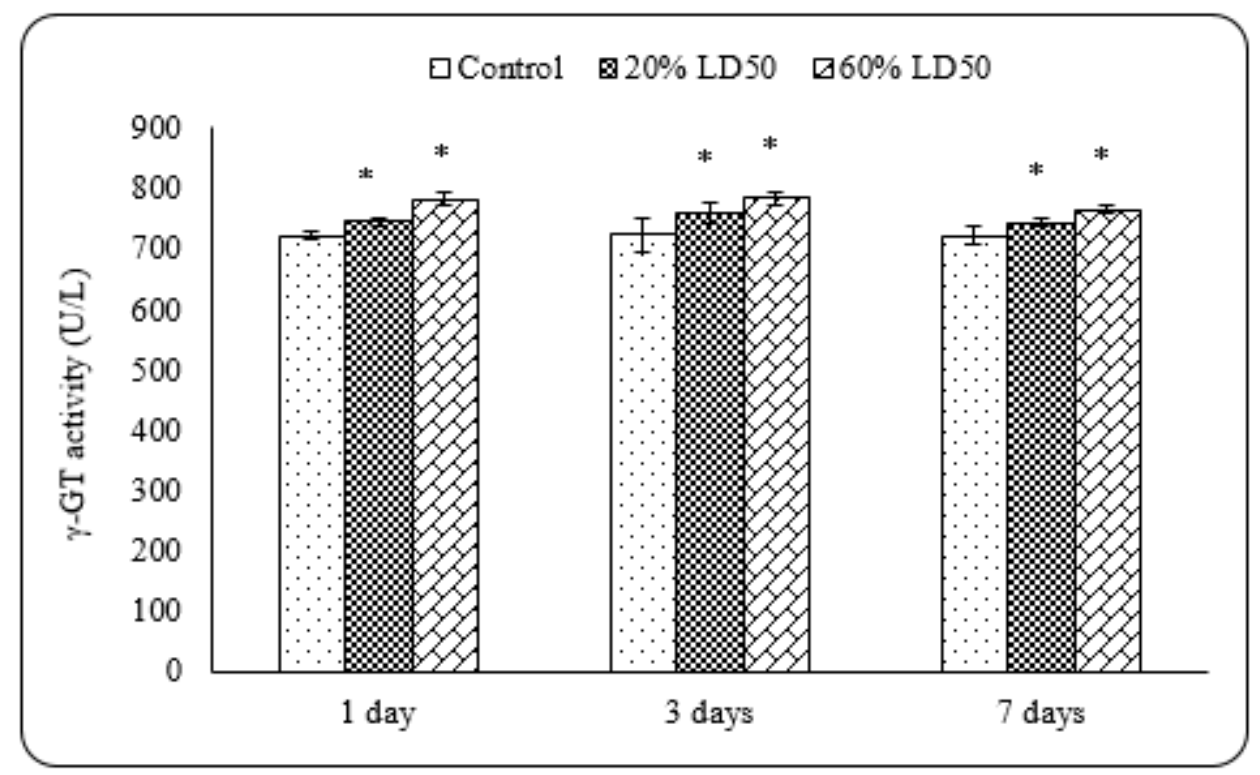

\section{Figure 2}

$\mathrm{Y}$-Glutamyl transferase ( $\mathrm{\gamma}$-GT) activity in the survivors of Theba pisana treated with 20 and $60 \%$ LD50 $A B M$, together with their controls, for various time intervals. Bar represents mean $(n=3)$ and vertical line represents the standard error (SE). The star indicates a significant difference from the control $(p \leq 0.05)$. 


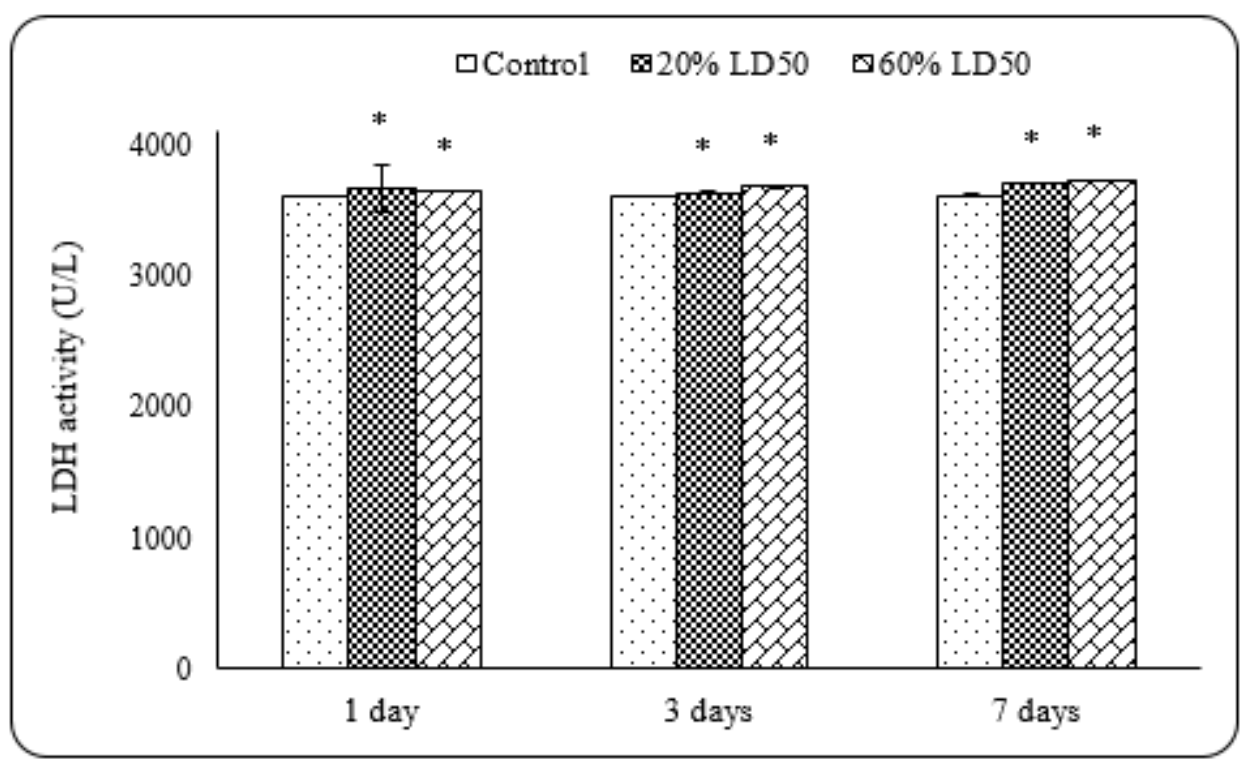

\section{Figure 3}

Lactate dehydrogenase (LDH) activity in the survivors of Theba pisana treated with 20 and $60 \%$ LD50 $A B M$, together with their controls, for various time intervals. Bar represents mean $(n=3)$ and vertical line represents the standard error (SE). The star indicates a significant difference from the control $(p \leq 0.05)$.

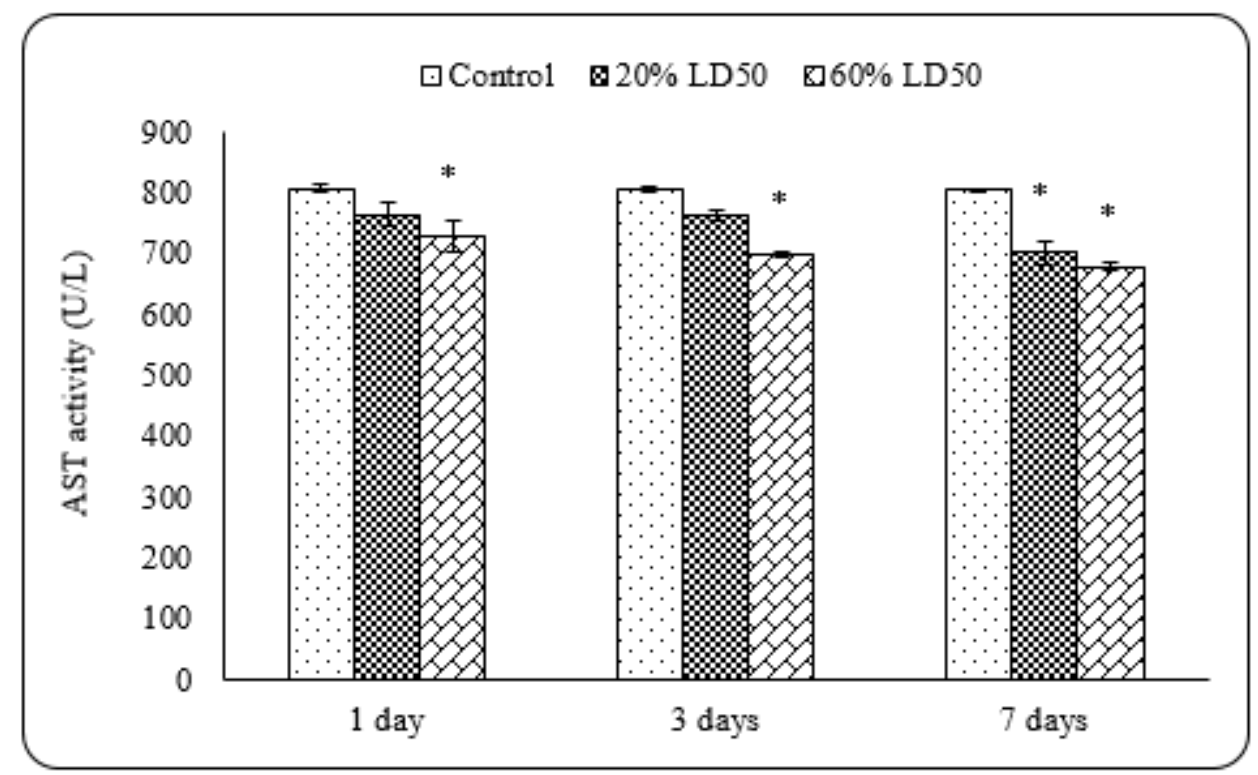

\section{Figure 4}

Aspartate aminotransferase (AST) activity in the survivors of Theba pisana treated with 20 and $60 \%$ LD50 ABM, together with their controls, for various time intervals. Bar represents mean $(n=3)$ and vertical line represents the standard error (SE). The star indicates a significant difference from the control ( $p \leq$ 0.05). 


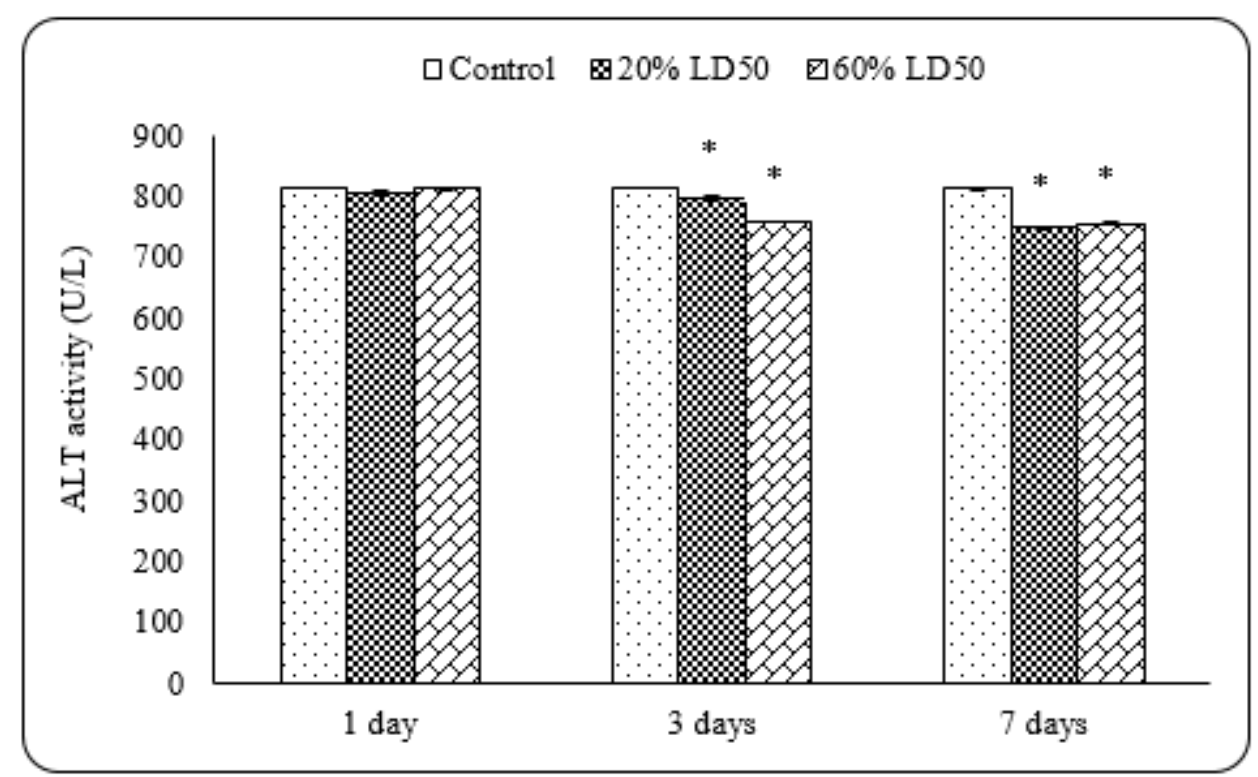

Figure 5

Alanine aminotransferase (ALT) activity in the survivors of Theba pisana treated with 20 and $60 \%$ LD50 $A B M$, together with their controls, for various time intervals. Bar represents mean $(n=3)$ and vertical line represents the standard error (SE). The star indicates a significant difference from the control $(p \leq 0.05)$.

\section{Supplementary Files}

This is a list of supplementary files associated with this preprint. Click to download.

- Graphicalabstract.tif 